\title{
A Preliminary Investigation into Multiple Pollutant Exposures and Nephrotoxicity Injury Among Goldsmiths
}

\begin{abstract}
:
Background: Goldsmiths are known for using potent toxic chemicals which pose a health risk to workers which occur either by inhalation or by dermal contact. Chemicals taken up by the body causes damage to vital organs of body such as kidneys, lungs etc., there by affecting their normal physiology and function. Objective: Present study reports the assessment of Nephrotoxicity among goldsmiths who are employed from 4 years-50years in jewellery making units. Methods: The study involved various environmental parameters such as determination of TSPM for air pollutant analysis, biological parameters such as urinary $\beta$-2-microglobulin, urinary Creatinine, urinary albumin, urinary total protein concentrations, and serum concentrations of Glutathione-S-Transferase, Catalase, extracellular Super Oxide Dismutase and total protein in both control and test samples. Result: Environmental, biological parameters of exposure and renal dysfunction were examined in a group of goldsmith workers $(n=22)$ and in an un-exposed control group ( $n=22)$. The parameters examined were compared between the two groups and related to different exposure parameters. The TSPM concentrations ranged between 75-664 $\mu \mathrm{g} / \mathrm{m} 3$. The concentrations of $\beta-2-$ microglobulin were $0.14-1.2 \mathrm{mg} / \mathrm{g}$ of Creatinine, In exposed group Serum concentration of Glutathione-S-Transferase was $1.19 \pm 0.48$, Catalase $5.1 \pm 0.61$, extracellular Super Oxide Dismutase $281.2 \pm 90.8$, and total protein $5.9 \pm 0.83$. However there were no significant changes in the urinary albumin and urinary total protein concentrations between the exposed and the control population.
\end{abstract}

Key Words: Nephrotoxicity, TSPM, $\beta$-2-microglobulin, urinary Creatinine, and urinary albumin, urinary

Sulthana Shahajahan ${ }^{1}$, Ravichandran $B^{1}$, Reddy Shreedhar ${ }^{2}$, Sen Somnath ${ }^{1}$, Shruthi B.R ${ }^{2}$

1 Industrial Hygiene \& Toxicology Division, Regional Occupational Health Centre (S), Bangalore, Karnataka, India

2 Nagarjuna College of Engineering and Technology, Devanahalli, Bangalore -562 110 total protein, glutathione-s-Transferase, Catalase, extracellular super oxide dismutase and total protein.

\section{Introduction}

A number of occupational hazards in the form of acute, chronic, immunologic, neuro-toxic, reproductive and carcinogenic effects have been reported to be associated with exposures to different types of chemicals.$[1,2]$ The presence of various environmental chemicals, heavy metals and many toxic agents in the workplace and in the surrounding environment poses a potential health hazard .[3] Goldsmith workshops operate in congested areas, where workers are directly exposed to toxic fumes for long hours, as they work without any protective gear and in the absence of any sufficient exhaust system. Occupation involves burning concentrated chemicals using furnaces, gas cylinders there by emitting hazardous gasses and fumes which pose a serious threat to public health and environment. The acid fumes can cause respiratory, eye and skin ailments in workers.
Occupational exposure to heavy metals has been reported in many occupations. [4] Several proteins have been used as biomarkers of renal damage such as functional markers (e.g., serum creatinine and $\beta 2$ micro globulin), urinary proteins of low or high molecular weight (e.g., albumin, transferrin, rheumatoid factor, etc.), enzymes (e.g., $\quad \mathrm{N}$ - acetylglucosaminidase, $\beta$-galactosidase) in urine. $[5,6,7]$ Biomarkers for nephrotoxicity were reviewed in WHO. [8] and are well validated in relation to exposure to cadmium.[9,7] The heavy metals such as $\mathrm{Cd}$, $\mathrm{Hg}$, $\mathrm{Pb}$ and $\mathrm{Zn}$ affect many tissues like brain, liver, kidney etc. Kidney is the site of degradation and detoxifications of most of the toxic substances.[10]Cadmium and lead are divalent cations with a propensity to settle in the proximal tubule of the nephron, leading to nephrotoxicity.[11]

Goldsmiths are known for using potent toxic chemicals like amile 
nitrates(polishing material), ammonium chloride, aniline dyes (stone ink), aqua regia, cadmium, mercury, nitric acid potassium cyanide, sulphuric acid etc. These chemicals are used for melting, refining, welding, electroplating and polishing the gold metal.[12] The occupational exposure to mercury released from gold extraction by amalgamation process affects the renal function, as evidenced by the urinary mercury as biomarker. The low-molecular weight proteins that escape complete reabsorption when the proximal tubular cells are overloaded or damaged have been used as markers of damage or dysfunction of the kidney cells.[13,14] Some of the best-characterized tubular proteins to detect proximal tubular injury are $\alpha 1$ - and $\beta 2$-microglobulin, retinol-binding protein, and cystatin C.[15]ß2-Microglobulin is a 12-kd protein and is part of class I major histocompatibility complex and is presented at the membrane of nucleated cells. $[16,17,18]$ The concentration of $\beta 2$-microglobulin increases with glomerular diseases, and an increase in $\beta 2$-microglobulin may be predictive for a decrease in renal function. [19]

\section{Methods}

A preliminary survey was made among shops located in Chickballapur a small town in Karnataka state, where in predominant occupation is jewel making. A detailed questionnaire was collected from 46 workers, the study plan and objective of our study was explained to all the owners of jewelry units. Being a unorganised sector industry, these shops employ very few people for making jewels, Hence only 22 goldsmiths were available from different shops in the study area who were continuously involved in ornaments making ( $8 \mathrm{hrs} /$ day/week) for a minimum of 4 years to 50 years. 22 controls were selected in the same study area not involving in this occupation. A short questionnaire was administered to each worker at the time of study. The questionnaire was designed to collect the demographic characteristics, history of occupation, total years of work experience, use of medicines, medical history, smoking habits and alcohol consumption.

\section{Environmental monitoring: Suspended particulate matter (SPM)}

Indoor air quality is one of the best methods to assess the possible human exposure level of air borne pollutants. The air sampling was done with the help of handy sampler (HDS-8), and personal samplers (PS1) and (PS2). The suitable sampling points of 5 different areas within the shop floor were selected and sampling was continued over a period of 8 hours/day up to a week. The sampler sucks measured volume of air by adjusting the flow rate of the air into 1.6 LPM (human breathing rate), which has came through the pre-weighed glass fiber filter paper where the SPM were collected. Air pollutant analysis involves estimation of total suspended particulate matter (TSPM) using the formula

$$
T S P M=\frac{W \times 10^{6}}{V}
$$

Where $\mathrm{W}$ is the weight of dust in grams and $\mathrm{V}$ is the volume of air sampled in $\mathrm{m}^{3}$.

\section{Biological monitoring:}

Urine analysis:Urine was collected in sterile vials from control and exposed subjects and was brought to laboratory for the analysis. Urinary $\beta$-2-microglobulin concentration was measured using 96 well AESKULISA $\beta$-2-microglobulin kit, Urinary Creatinine concentration was determined by picrate method, urinary albumin concentration was determined using bromo cresol green method and urinary total protein concentration by biuret method.

Enzyme and protein analysis: Blood samples were collected in heparin coated tubes and Samples were transported to laboratory after collection and stored at $-20^{\circ} \mathrm{C}$ in the laboratory prior to use. To evaluate the enzyme levels in serum, Glutathione-S-Transferase was estimated using Beutler method. Catalase was estimated by Chance and Machly method, extracellular SOD by McCord and Fridrich method and total protein was estimated using Bradford method. The analysis of variance (ANOVA) test (SSPS 14.2 software) was used for data analysis.

\section{Result}

Table 1: Study population characteristics $(\mathrm{N}=46)$

\begin{tabular}{|c|c|c|}
\hline \multicolumn{2}{|r|}{ Variables } & Number of workers \\
\hline \multirow[b]{2}{*}{ Age } & $20-30$ & 25 \\
\hline & $30-55$ & 21 \\
\hline \multirow{3}{*}{ Job Category } & $\begin{array}{l}\text { Soldering, melting, } \\
\text { Polishing, cutting }\end{array}$ & 40 \\
\hline & Cutting & 02 \\
\hline & Polishing & 04 \\
\hline \multirow{3}{*}{$\begin{array}{l}\text { Educational } \\
\text { status }\end{array}$} & Illiterate & 03 \\
\hline & School & 42 \\
\hline & Graduate & 01 \\
\hline \multirow{2}{*}{ Marital status } & Single & 17 \\
\hline & Married & 29 \\
\hline \multirow{2}{*}{ Smoking } & Smoker & 17 \\
\hline & Non smoker & 29 \\
\hline \multirow{2}{*}{ Tobacco chewing } & Chewer & 09 \\
\hline & Non-chewer & 37 \\
\hline \multirow{2}{*}{ Alcohol intake } & Yes & 09 \\
\hline & No & 37 \\
\hline \multirow{2}{*}{ Food habit } & Vegetarian & 10 \\
\hline & Non-vegetarian & 36 \\
\hline \multirow{2}{*}{ Chronic disease } & Yes & 02 \\
\hline & No & 44 \\
\hline
\end{tabular}




\section{ENVIRONMENTAL MONITORING}

\section{Total Suspended Particulate Matter (TSPM)}

The mean TSPM level found at jewellery unit was $360 \pm 205 \mu \mathrm{g} / \mathrm{m}^{3}$ (Fig 1. range: $75-664 \mu \mathrm{g} / \mathrm{m}^{3}$ ). The suspended particulate matters are the air borne pollutants, causes health effects like respiratory tract infections, pneumoconiosis, irritations of eye, mouth, skin, and $\mathrm{GI}$ tract as well.

Figure 1: Concentration of Total Suspended Particulate Matter (TSPM) in the Jewellery making Units

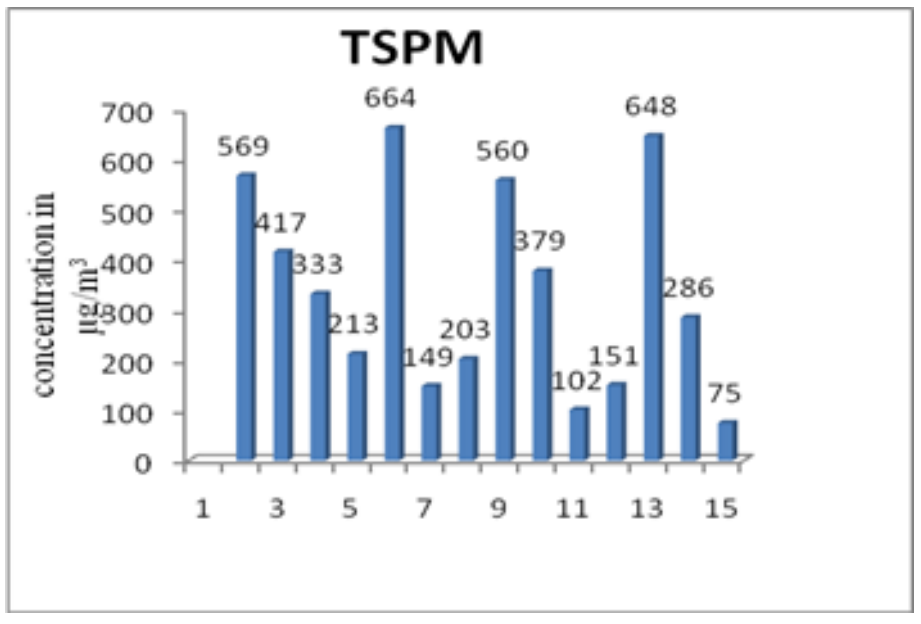

\section{BIOLOGICAL MONITORING}

\section{及-2 micro globulin Concentration}

Table 2: Concentration of $\beta-2$ micro globulin

\begin{tabular}{|l|c|c|c|}
\hline \multicolumn{1}{|c|}{ Subjects } & N & Mean \pm SD & Range \\
\hline Goldsmith workers & 19 & $0.53 \pm 0.42$ & $0.14-1.2$ \\
\hline Control & 12 & $0.66 \pm 0.23$ & $0.31-1.14$ \\
\hline
\end{tabular}

Units : mg $\beta$-2 micro globulin /gram of Creatinine

\section{ENZYME ANALYSIS}

In our work, serum enzyme levels significantly vary in test samples when compared to normal range (Table 3). This indicates that there is a possibility of renal tubular dysfunction.

Table 3: Serum enzyme and protein concentrations in exposed groups

\begin{tabular}{|l|c|c|}
\hline \multicolumn{1}{|c|}{ Parameters } & $\begin{array}{c}\text { Values Obtained } \\
\text { (Mean } \pm \text { SD) }\end{array}$ & $\begin{array}{c}\text { Normal Range } \\
\text { (Mean } \pm \text { SD) }\end{array}$ \\
\hline Glutathione-S-Transferase & $1.19 \pm 0.48$ & $1.17 \pm 0.53$ \\
\hline Catalase & $5.1 \pm 0.61$ & $1.3 \pm 0.8$ \\
\hline $\begin{array}{l}\text { Extracellular Superoxide } \\
\text { Dismutase (ESOD) }\end{array}$ & $281.2 \pm 90.8$ & $494.3 \pm 117.8$ \\
\hline Total Protein & $5.9 \pm 0.83$ & $7.5 \pm 0.48$ \\
\hline
\end{tabular}

\section{Discussions}

Occupational exposure to toxic chemicals and heavy metals are increased due to industrialization .The goldsmith workers are exposed to potentially toxic chemicals, metal fumes and dust particles released in the process of ornamental making. In order to evaluate the occupational exposure to these hazardous substances, air sampling was done for suspended particulate matter and gaseous pollutants. In our present study total suspended particulates (TSPM) were collected with handy sampler from the indoor work environment at 15 shops. The tspm levels were ranged from $75-664 \mathrm{mg} / \mathrm{m}^{3}$ with the average of $339 \mathrm{mg} / \mathrm{m}^{3}$. These values indicate that the working area in the shop accumulated heavy particulates which may be harmful to the worker employed in that shop. The results showed that the workers are more prone to particulate contaminant.

Hong and Chia (1998) stated that the detection of renal tubular proteins and enzymes may precede glomerular involvement, as several of these tubular proteins and enzymes are detectable even before the appearance of microalbiminurea. Jung et al. (1988) stated that, urinary excretion of renal tubular enzymes and low molecular weight proteins have been recommended as useful markers for detection of minor changes in proximal tubular function long before elevation in other markers as Proteinuria and rise in serum Creatinine. In a study by Roels et al. slight tubular effects were detected as shown by an increased urinary excretion of retinol binding protein or $\beta_{2}-$ Microglobulin workers exposed to mercury. Bernad and co-workers showed that increased excretion of retinol binding protein is a sensitive indicator of early tubular damage and retinol binding protein was suggested to show a close correlation to $\beta_{2}-$ Microglobulin. In our study we analyzed four urinary proteins $\left(\beta_{2}\right.$-microglobulin, albumin, Creatinine, total protein) of different molecular sizes and three tubular enzymes (Glutathione-S-Transferase Catalase Extracellular Superoxide Dismutase (ESOD)). The purpose was to discriminate between glomerular and tubular dysfunction. Measurement of $\beta_{2}$-microglobulin and creatinine in urine made it possible to calculate the relative clearance of $\beta_{2}$-microglobulin, which is considered as a sensitive measure of tubular function. Urinary concentration of creatinine is often used as a screening tool for glomerular dysfunction in clinical practice. Urinary creatinine does not, however, increases until the glomerular filtration rate is substantially reduced, and is therefore considered as an insensitive indicator of glomerular damage (S Langworth et al). The finding of normal excretion of albumin in the heavy metal exposed group does not imply any effect of heavy metals on glomerular filtration of heavy metals at the exposure levels. In earlier studies, increased protenuria has been found at much higher exposure to heavy metals. Normal $\beta_{2}$-microglobulin levels were found to be $0.2 \mathrm{mg} / \mathrm{g}$ of Creatinine), its elevated levels serve as indication for alteration of Tubular reabsorption (Boege 1998). In our study the $\beta_{2}$-microglobulin levels ranged from $0.14 \mathrm{mg} / \mathrm{g}$ of Creatinine $-1.2 \mathrm{mg} / \mathrm{g}$ of Creatinine. However 
that we found two values in our test samples to be higher than the normal levels $8.09 \mathrm{mg} / \mathrm{g}$ of Creatinine and $19.25 \mathrm{mg} / \mathrm{g}$ of Creatinine and one value in the control sample was found to be $6.59 \mathrm{mg} / \mathrm{g}$ of Creatinine the exceptionally high values may be due to the other health problems from which the worker suffers. Three tubular enzymes (Glutathione-S-Transferase, Catalase, Extracellular Superoxide Dismutase (ESOD) were analysed in both test and control samples. There were slight increase in the GST and Catalase levels where as ESOD and total protein levels were within the normal range. Increase in the GST and Catalase levels indicates possibility of tubular injury, however due to less sample size and time limit results can't be concluded. Study needs to be conducted with larger sample size so as to determine the nephrotoxicity caused by mixture of chemicals which the goldsmith is exposed to.

In the conclusion, we found no evidence of glomerular damage or defects in tubular re absorption at the present low exposure to heavy metals. Nevertheless, the results indicate slight tubular cell damage in the group occupationally exposed to heavy metals.

\section{Future scope}

The purpose of accomplishment of this study was to make it as a medium for the awareness of occupational health among gold smiths. Health in any occupation is met with diversified threats and the awareness of its existence and the potential harms it faces, will benefit the people who are currently employed and the people who will be employed in the years to come. The study forms a basis for future studies to be conducted on the Nephrotoxicity. Due to economic, time and authoritative constraints, the analysis in this study was restricted to the detection of four urinary biomarkers beta-2-microglobulin, Creatinine, albumin and total protein and some of the enzyme analysis. But since the result obtained were positive for the presence of biomarkers in the target population. These effects include short term effects such as minor physical discomfort and long term dangerous effect such as renal damage that can be studied through various nephrotoxicity studies. To avoid these problems the workers must try to practice the intervention measures, such as wearing of masks, nose guards during their work period and also by adopting proper ventilation with exhaust. Once the entire study gets validated at the highest required authoritative level, the study will not only serve as a media of occupational health awareness for goldsmiths of our target population, but also at the regional and possibly national level.

\section{Limitations of study}

Since the study was a walkthrough type mainly to find out the health problems associated with the chemicals being involved in the jewellery making process and the sample size is very small, the statistical design could not be applied. But the results were very much useful for goldsmiths to take control measures.

\section{References}

1. Tirthankar Studipto Roy, Occupational Health- An overview. Journal of the Indian Medical Association 2000, 98(8): 431.

2. Gupta.K.C Challenges before occupational health professionals. Indian journal of occupational health and Environmental Medicine 1998,2: 186.

3. Guerin M.R. Formation and physic-chemical nature of sidestream Smoke IARC-Environmetnal carcinogens. Methods of Analysis and Exposure measurement, IARC Scientific Publications Lyon 1987, 9(81): 11-23

4. Elinder,C.G.M . Health from environmental or occupational exposure to Cadium. Acta Pharmacologica et Toxicologica 1986, 59, Suppl.7.

5. Cardenas A, Roels H, Beranard Am, Barbon R, Buchet JP, Lauwerys $R R$ et al. markers of early renal changes induced by industrial pollutants. 1 application to workers exposed to mercury vapour. Br J Ind Med 1993a,50:17-27

6. Cardenas A, Roels H, Beranard Am, Barbon R, Buchet JP, Lauwerys $\mathrm{RR}$ et al. markers of early renal changes induced by industrial pollutants.2 application to workers exposed to mercury vapour. Br J Ind Med1993b,50:28-36

7. Roels $\mathrm{H}$, Beranard AM, Cardenas A, Buchet JP, Lauwerys RR, Hotter $G$ et al. markers of early renal changes induced by industrial pollutants. 1 application to workers exposed to mercury vapour. Br J Ind Med1993,50:37-48

8. WHO (1991) IPCS Environmental Health Criteria 119: Principles and methods for the assessment of Nephrotoxicity associated with exposure to chemicals. Geneva, World Health Organization,266pp

9. $\mathrm{WHO}(1992 \mathrm{a}) \mathrm{IPCS}$ Environmental Health Criteria 134: Cadmium. Geneva, World HealthOrganization,280pp

10. Rao, D.M, AP. Devi and A.S. Murthy.Relative toxicity of endosulphan its isomers and formulated products to the fresh water fish Labeo rohita J.Toxicol Environ HIth 1980, $6: 323$

11. H.C. Gonick .Nephrotoxicity of Cadmium \&lead, October 2008, 335-352.

12. Jayaprakash k. Acquired methaemoglobinemia (Met $\mathrm{Hb}$ ) in goldsmiths- a hitherto unobserved occupational hazard. Indian journal of occupational and environmental medicine 2003,7(1).

13. Tolkoff-Rubin NE, Rubin RH, Bonventre JV Noninvasive renal diagnostic studies. Clin Lab Med8 1988:507-526

14. Scherberich JE Urinary proteins of tubular origin: basic immunological and clinical aspects. Am J Nephrol 1990,10:43-51 
15. Westhuyzen J, Endre ZH, Reece G, Reith DM, Saltissie D, Morgan TJ(2003)Measurement of tubular enzymuria facilitates early detection of acute renal impairment in the intensive care unit. Nephrol Dial Transplant 2003, 18:543-551

16. Bernard AM, Vyskocil AA, Mahieu P, Lauwerys RR Assessment of urinary retinol-binding protein as an index of proximal tubular injury. Clin Chem1987, 33:775-779

17. Donaldson MDC, Chambers RE, Woolridge MW, Whicher JT. Stability of alpha 1-microglobulin, beta 2-microglobulin and retinol binding protein in urine. Clin Chim Acta 1989,179:73-79

18. Schaub S, Wilkins JA, Antonovici M, Krohkin O, Weiler T, Rush $D$ et al. Proteomic-based identification of cleaved urinary $\beta 2$-microglobulin as a potential marker for acute tubular injury in renal allografts. Am $\mathrm{J}$ Transpl 2005, 5:729-738.

19. L.J.M. Reichert.R.A.P. Koene.J.F.M .Urinary excretion of $\beta 2-$ Microglobulin predicts renal Outcome in Patients with Idiopathic Membranous Nephropathy. J. Am. Soc. Nephrol 1995, 6:1666-1669 